\title{
The impact of emotional intelligence on faculty members' knowledge sharing behaviors
}

\author{
Masoomeh Arabshahia ${ }^{a}$, Mohammad Lagzian ${ }^{\text {, }}$, Fariborz Rahimnia ${ }^{b}$ and Azar Kafashpour
}

${ }^{a}$ Ph.D. Student of Organizational Behavior Management, Ferdowsi University of Mashhad, Mashhad, Iran ${ }^{b}$ Associate Professor of Ferdowsi University of Mashhad, Mashhad, Iran

\section{CHR O N I C L E}

Article history:

Received May 16, 2013

Received in revised format

12 September 2013

Accepted 26 October 2013

Available online

October 312013

Keywords:

Knowledge sharing

Knowledge sharing behavior

Emotional intelligence

\begin{abstract}
A B S T R A C T
Universities and institutions of higher education with a professional, special, educational and cultural environment, play an important role in effective knowledge management and preparing the background for knowledge sharing. Faculty members are known as the main elements of the university who own mental and intellectual property. Their knowledge sharing under certain conditions along with knowledge sharing behaviors improve individual and organizational operations. Moreover, the tendency to do these actions is the most important factor in knowledge sharing behavior and emotional intelligence (EQ), as one of the social intelligence factors, can guide individual thinking and activity. This study examines the impact of emotional intelligence on faculty members' knowledge sharing behaviors. Regarding the purpose and nature, this study was functional and its methodology was exploratory and due to evaluation of the relations and impacts among variables, it was a correlational method. Data collection included interviews with experts for the qualitative part and a questionnaire for the quantitative part. The qualitative findings indicate different emotional intelligence dimensions, which includes self-awareness, social skills, coping with pressure, adaptability and overall creation. In addition, the result of EQ dimensions on knowledge sharing behavior reveal that "social skills, coping with pressure, and overall creation" share a link with faculty members' research behavior among the four dimensions of knowledge sharing behavior and that "adaptability" has no significant relationship with knowledge sharing behavior.
\end{abstract}

(C) 2013 Growing Science Ltd All rights reserved.

\section{Introduction}

Knowledge is considered as a rich source of competitive advantage for any organization. To succeed in the competitive environment, all organizations assume it is necessary to obtain knowledge more effectively than others do. Today, moving towards using knowledge makes knowledge management a key strategic instrument to improve the performance of the firms and sharing and applying the knowledge (Seonghee \& Boryung, 2008). Knowledge sharing is an essential area of knowledge management located within processing knowledge, where knowledge is generated and applied. In fact, knowledge management means providing suitable information for appropriate people at the right 
time so that people could generate and share the information. Sharing knowledge means providing the chance of knowledge acquisition to those who need it. In other words, knowledge sharing is a kind of process where the knowledge processed by a person, changes in a way, which could be understood and used by the others. Therefore, it seems that one way of successful knowledge management is the usefulness and effectiveness of knowledge sharing (Seonghee \& Boryung, 2008).

Among business units, universities and institutions of higher education with an educational and academic, environment are considered suitable places for knowledge sharing. Faculty members also, as the building and basic components of the university and the mental and intellectual investment banks, share their knowledge under certain conditions (Nonaka \& Takeouchi, 1996). Since sharing knowledge more than any other action depends on people and their views (Gouza 2006), and the joy of helping others influences on knowledge sharing behavior (Shin et al., 2008), experts believe that the tendency of knowledge sharing is predictable through emotional intelligence component, and managers can simply select people with high emotional intelligence and enhance this behavior by training them (Karkoulian, 2010).

The subject of this study is faculty members' knowledge sharing behaviors and the impact of emotional intelligence on it. This study was conducted in both qualitative and quantitative forms with the priority on the qualitative. In the first phase, the elements of knowledge sharing behaviors are diagnosed and determined and in the second phase, descriptive statistics are included and the analysis has been done to detect the significant relationship between the dimensions of emotional intelligence data with the components of knowledge sharing.

\section{Theoretical Framework}

Emotional intelligence and its dimensions (Goleman, 1999) has been accepted as the theoretical framework of this study and is implemented after studying and determining the knowledge sharing behavior dimensions in the field of this study and testing their impacts.

\subsection{Emotional intelligence}

Emotional intelligence means becoming aware of one's emotions and dominating it. This intelligence is a form of social intelligence that involves the capability of understanding others' feeling, recognizing and using it for thinking to influence others. Goleman (1999) believed that emotional behaviors are some skills in which the owner can control his/her emotions with self-awareness and improve it through his/her own management. In addition, individual can understand its impact through empathy and enhance his/her or others' mood by managing the relationship.

Goleman and Cherniss (2001), stated that emotional intelligence includes the individual and community capability and its constituent components includes self-awareness, social skills, coping with pressure, adaptability and overall creation.

\subsection{Knowledge Sharing}

Knowledge sharing can be stated as sharing the proper information, ideas, suggestions and expertise with others in the organization. In other words it is a set of behaviors that involve the exchange of information or helping others. There is another definition of knowledge sharing as a systematic activity in order to transfer and exchange knowledge and experiences among a group or an organization with a common goal (Salovey \& Mayer, 1989).

\subsection{Knowledge Sharing Behavior}

Set of activities which are associated with the exchange of knowledge in which the key factors such as content of knowledge, organizational condition, appropriate media and environment play essential role on the success of organizations. 


\subsection{University and Faculty Members}

Universities as an educational and research environment are appropriate places for knowledge sharing. In fact, universities like other organizations have competitive environments, so it is necessary to make sure that in this environment, knowledge is appropriately generated, transferred and shared among individuals. Faculty members are considered as primary sources of production and application in academic institutions and their major activities are teaching, researching and doing related professional activities (Seonghee \& Boryung, 2008). These people tend to share their knowledge through formal and informal groups, electronic communications and training workshops with colleagues (Hulland, 1999).

\section{The proposed study}

This study was planned in two qualitative and quantitative sections and it attempted to define different dimensions of knowledge sharing behaviors and to identify the quality of relation and impacts of emotional intelligence on knowledge sharing behaviors.

\subsection{Purpose of the study}

The primary purposes of this study are as follows: 1) Identification of different dimensions of knowledge sharing behaviors among faculty members, 2) Measurement of the impact of emotional intelligence on knowledge sharing behaviors of faculty members.

\subsection{Research questions}

Main research questions were: 1) What are the different dimensions of knowledge sharing behaviors among faculty members? 2) How much impact does emotional intelligence have on knowledge sharing behaviors of faculty members?

\subsection{Variables measured in this study}

In this study, the independent variable is emotional intelligence and knowledge sharing behavior is considered as the dependent variable. In this regard, emotional intelligence dimensions and their related definitions raised from the theoretical research framework were considered as other independent variables; and knowledge sharing behaviors' features extracted by study of fieldworks, as the other dependent variables.

\section{Methodology}

The criteria for choosing a method are based on the nature of the research, its environment, possible limitations and underlying paradigm (Danaiee \& Mozaffari, 2008). The subject of the research is to identify the knowledge sharing behavior dimension and components of faculty members and examining the effect of emotional intelligence. So, in the first phase, qualitative methods were used to identify the dimensions and components of knowledge sharing behavior and in the next step, quantitative methods were used to investigate the impact of emotional intelligence on knowledge sharing behavior. Hence, the mixed method was used in this study (Creswell \& Clark, 2007).

\section{Statement of the problem}

In this study, first qualitative methods and interviews were used to identify the dimensions and components of knowledge sharing behavior of faculty members, and then the results became the basis for the next phase, which is the quantitative part. So the mixed method was used in this study. 


\subsection{Research strategy in qualitative part}

There are a variety of strategies in qualitative research: survey strategy, case study strategy, action research strategy. In this study, in order to answer the first research question, to identify the knowledge sharing behavior dimension of faculty members and due to the exploratory nature of this study, the survey strategy was used. Survey research is based on naturalism and used for studying phenomenon in its natural environment.

\subsection{Research strategy in quantitative part}

In an overall category, strategies of quantitative research include trial strategy and survey strategy. In this study, survey strategy was used to answer the second question.

\subsection{Participants}

The research participants are faculty members of the management departments of different state universities of Iran. In the qualitative part, which seeks to diagnose the knowledge sharing behavior dimensions, the interview with experts was used. In the second part, which assess knowledge sharing behavior dimensions extracted from interviews and examine the emotional intelligence effect on them, all faculty members of the management departments of state universities have been selected as participants.

\subsubsection{Sampling of the qualitative part}

Qualitative sampling includes a small sample with in depth examination where the objective is to have good insight on examining phenomenon. Its sampling is goal oriented and not accidental and the selection of units is based on the purpose of the study. In some resources the number of participants for a homogenous group is said to be six to eight and for the heterogeneous group about 12 to 20 (Bollen, 1998). In the qualitative part of this study, eight faculty members, who are professional and knowledgeable in this field, were interviewed. In this part, the theoretical saturation rule was used, which is an approach to determine sampling adequacy in qualitative research (Teddlie, \& Tashakori, 2003).

\subsubsection{Sampling of the qualitative part}

The quantitative study samples were randomly selected, so that the sample size and representative sample could be properly at the hands of the researcher (Teddlie \& Tashakori, 2003). The sample size was determined by using the Morgan and Kerjesi Table so that the statistical participants included 145 participants and 108 participants were selected as a sample size.

\subsection{Data collection tools}

In this study, the following tools were used for data collection:

\subsubsection{Interview}

Through this study, the qualitative data was gathered from interviews with experts. Before the interview sessions, participants were informed about the topics through email, telephone or face-toface explanations. Due to the flexible nature of the interview, it was used in the semi-structured format (Bollen, 1998; Tashakkori \& Teddlie, 2003).

\subsubsection{Questionnaire}

In the quantitative part of the study, a two-part questionnaire was used in order to evaluate the effects of the emotional intelligence dimension on the knowledge sharing behavior of faculty members which were extracted from the theoretical foundations of the research. The questionnaire of the 
knowledge sharing behavior was set based on the findings of the interviews, and the emotional questionnaire was a five-point Likert-type questionnaire.

\subsection{Reliability and validity in qualitative research}

Due to an interview used in the qualitative part, the researcher has performed a comprehensive study to explain the goal of interviewing, ignoring the previous knowledge and observed all criteria to have an effective interview. So this research is reliable and due to using supervisors and advisors' opinions, pluralism and validation were obtained.

\subsection{Reliability and validity of the quantitative part of the research}

Determining the validity of quantitative research means that the research measures what it is intended to do. In this study, for the validation of the knowledge sharing behavior questionnaire, the confirmatory factor analysis was used and it has been determined that all factorial loads greater than 0.5 were significant, items that had factorial loads less than 0.5 due to proper composite validity that was more than 0.7 were significant. The main way to assess the coefficient in the quantitative approach is the Cronbach coefficient alpha. Cronbach coefficient alpha is 0.892 for all of the questions of knowledge sharing behavior and 0.901 for EI. The data obtained indicates that reliability is high.

\section{Analyzing and interpreting data}

In this study, to answer the first question which was to identify the knowledge sharing behavior of faculty members, the content analysis method was used. Unit of analysis or evaluation can be words, sentences, themes and individuals. In this study, content analysis was implemented because it is one of the best analytic techniques for qualitative research.

After examining the interviews for the content analysis, different colors of markers or pens were used to highlight desired parts and identify unknown parts. Also, the incision and placement and text sorting approach were used. So in this way, the words that were semantically more appropriate were set together, and by examining the interviews several times and classifying similar sentences, the components of knowledge sharing behavior from the faculty members' point of view were identified and extracted.

\subsection{Qualitative result of interviews}

Content analysis like any other sociological surveys has these steps: initial analysis, obtaining raw materials of the research, analyzing and interpretation of the results. These phases are more adaptable with the statement of the problem and research process. In this study, after analyzing the interviews the text incision was used and the variables, which are knowledge sharing behavior components, were defined. Then due to the concepts and variables' relationships, the knowledge sharing behavior dimensions were discovered. Findings of interviews revealed that the knowledge sharing behavior of faculty members can be examined in four dimensions, which include research activities, educational activities, professional activities and cultural activities.

\subsection{Quantitative results}

In the quantitative part, in order to summarize the responses to the questionnaire, mean, median, variance and scope change indexes were calculated for each question and to examine the correlation between variables, the Halland two-step procedure and coefficients of determination and path coefficient were applied . 


\subsection{Correlation and effect examining}

For examining the effect of emotional intelligence components as independent variables on knowledge sharing behavior dimensions as dependent variables, the following result were obtained from examining the correlation between emotional intelligence dimensions and knowledge sharing behavior dimensions.

1 - "Self-awareness" as one of the emotional intelligence dimensions has inverse relationships with the cultural activity and has no significant relationship with other fields of knowledge sharing behaviors.

\section{Table 1}

The correlation between self-awareness \& KSB dimensions

\begin{tabular}{|c|c|c|c|c|c|}
\hline Dimensions of KSB & Statistic & $\begin{array}{c}\text { Research \& } \\
\text { Study }\end{array}$ & Education & $\begin{array}{c}\text { Professional and } \\
\text { Occupational }\end{array}$ & Cultural \\
\hline & Coefficients correlation & -0.102 & -0.195 & -0.174 & -0.449 \\
\hline Self-awareness & $\mathrm{p}$-value & 0.326 & 0.059 & 0.093 & 0.00 \\
\hline
\end{tabular}

- According to Table 2, "social skills", the other dimension of emotional intelligence, has a significant relationship (coefficient of 0.318 ) with faculty members' research behavior. However, no relationship is verified with knowledge sharing behavior dimensions.

Table 2

The correlation between social skills \& KSB dimensions

\begin{tabular}{cccccc}
\hline $\begin{array}{c}\text { Dimensions of } \\
\text { KSB }\end{array}$ & Statistic & Research \& Study & Education & $\begin{array}{c}\text { Professional and } \\
\text { Occupational }\end{array}$ & Cultural \\
\hline Social skills & Coefficients correlation & $\mathbf{0 . 3 1 8}$ & -0.202 & 0.005 & -0.145 \\
& p-value & $\mathbf{0 . 0 0 2}$ & 0.051 & 0.963 & 0.162 \\
\hline
\end{tabular}

- According to Table 3, "coping with pressure", one of the EQ dimensions, has shown a significant relationship (coefficient of 0.257 ) with faculty members' research behavior and has no relationship with knowledge sharing behavior dimensions.

Table 3

The correlation between coping with pressure and KSB dimensions

\begin{tabular}{llcccc}
\hline $\begin{array}{l}\text { Dimensions of } \\
\text { knowledge sharing } \\
\text { behaviors }\end{array}$ & \multicolumn{1}{c}{ Statistic } & $\begin{array}{c}\text { Research \& } \\
\text { Study }\end{array}$ & Education & $\begin{array}{c}\text { Professional and } \\
\text { Occupational }\end{array}$ & Cultural \\
\hline Coping with pressure & $\begin{array}{l}\text { Coefficients correlation } \\
\text { P-value }\end{array}$ & $\mathbf{0 . 2 5 7}$ & -0.113 & -0.097 & -0.143 \\
& $\mathbf{0 . 0 1 2}$ & 0.278 & 0.352 & 0.169 \\
\hline
\end{tabular}

According to Table 4, the "adaptability" dimension has no significant relationship with knowledge sharing behavior dimensions.

Table 4

The correlation between adaptability and KSB dimensions

\begin{tabular}{lccccc}
\hline $\begin{array}{l}\text { Dimensions of } \\
\text { knowledge sharing } \\
\text { behaviors }\end{array}$ & Statistic & $\begin{array}{c}\text { Research \& } \\
\text { Study }\end{array}$ & Education & $\begin{array}{c}\text { Professional and } \\
\text { Occupational }\end{array}$ & Cultural \\
\hline Adaptability & Coefficients correlation & 0.98 & 0.090 & -0.139 & -0.158 \\
& p-value & 0.349 & 0.388 & 0.181 & 0.128 \\
\hline
\end{tabular}


- According to Table 5, the "overall creation", the other dimension of emotional intelligence has a significant relationship (coefficient of 0.214 ) with faculty members' research behavior and has no relationship with knowledge sharing behavior dimensions.

\section{Table 5}

The correlation between overall creation and KSB dimensions

\begin{tabular}{cccccc}
\hline $\begin{array}{c}\text { Dimensions of } \\
\text { knowledge } \\
\text { sharing behaviors }\end{array}$ & Statistic & $\begin{array}{c}\text { Research \& } \\
\text { Study }\end{array}$ & Education & $\begin{array}{c}\text { Professional and } \\
\text { Occupational }\end{array}$ & Cultural \\
\hline Overall creation & Coefficients correlation & $\mathbf{0 . 2 2 4}$ & -0.106 & -0.010 & -0.132 \\
& p-value & $\mathbf{0 . 0 3 8}$ & -.308 & 0.924 & 0.205 \\
\hline
\end{tabular}

\section{Conclusion}

The findings show that among the emotional intelligence dimensions, which includes (self-awareness, social skills, coping with pressure, adaptability and overall creation), "adaptability" has no significant relationship with the knowledge sharing behavior and "social skills, coping with pressure and overall creation" have the most relationship with faculty members' research behavior among the four dimensions of knowledge sharing behavior. Self-awareness has shown a significant relationship with cultural activities behavior and has no significant relationship with other knowledge sharing behavior dimensions.

\section{Acknowledgment}

The authors would like to thank the anonymous referees for constructive comments on earlier version of this paper.

\section{References}

Bollen, K. A. (1998). Structural equation models. John Wiley \& Sons, Ltd.

Cozby, P., \& Bates, S. (2011). Methods in behavioral research.

Creswell, J. W., \& Clark, V. L. P. (2007). Designing and conducting mixed methods research. Thousand Oaks, CA: Sage publications.

Danaiee far, H. \& Mozaffari, Z. (2008). Enhance the reliability and validity in qualitative research management. Management Research Journal, 1(1), 131-162.

Goleman, D. (1999). Working with emotional intelligence, London.

Goleman, D., \& Cherniss, C. (2001). The emotionally intelligent workplace: How to select for, measure, and improve emotional intelligence in individuals, groups, and organizations. JosseyBass.

Gouza, A. (2006). Key factors of knowledge transfer with in university spin - off. Business Economics Department, Autonomous university of Barcelona, Spain retrieved June 8, 2009.

Hulland, J. (1999). Use of partial least squares (PLS) in strategic management research: a review of four recent studies. Strategic Management Journal, 20(2), 195-204.

Karkoulian, S. (2010). Correlates of organizational commitment and knowledge haring via Emotional intelligence. The business review, Cambridge, 15(1).

Nonaka, I., Takeuchi, H., \& Umemoto, K. (1996). A theory of organizational knowledge creation. International Journal of Technology Management, 11(7), 833-845.

Shin, C. H. , Ramayah, T. , \& Jahani , S. (2008 ). Using theory of reasoned action (TRA) to explain intention to share knowledge among academic. Retrieved May 3 , 2009 from www.apera.nic.edu.sg

Salovey, P., \& Mayer, J. D. (1989). Emotional intelligence. Imagination, cognition and personality, 9(3), 185-211. 
Seonghee, K., \& Boryung, J. (2008). An analysis of faculty perceptions: Attitudes toward knowledge sharing and collaboration in an academic institution. Library \& Information Science Research, 30(4), 282-290.

Tashakkori, A., \& Teddlie, C. (Eds.). (2003). Handbook of Mixed Methods in Social \& Behavioral Research. Sage. 